\title{
STUDIES ON THE ACTION OF SULFAPYRIDINE ON PNEUMOCOCCI
}

\author{
By WILLIAM C. SPRING, JR., FRANCIS C. LOWELL, AND MAXWELL FINLAND \\ (From the Thorndike Memorial Laboratory, Second and Fourth Medical Services (Harvard), \\ Boston City Hospital and the Department of Medicine, Harvard Medical School, Boston)
}

(Received for publication September 5, 1939)

In previous studies (1) it was shown that sulfanilamide in the concentrations ordinarily attained in therapy, exerts a marked bacteriostatic action on Type III pneumococcus when added to human blood in vitro or when found in the blood of patients with pneumonia after treatment. There was no appreciable bactericidal action except in some instances when large concentrations of the drug were used. This action was not associated with increased phagocytosis. Typespecific antibodies, whether actively acquired or when administered as therapeutic rabbit serum, induced pneumococcidal activity in the blood of the patients, and this was accompanied by increased phagocytosis. The combination of antiserum and sulfanilamide, when added in vitro or when used therapeutically, resulted in a greater bacteriostatic and bactericidal action of the blood than when either was used alone.

In the present paper the results of similar studies with sulfapyridine are reported. The action of this drug on Types I, II, and V pneumococci was studied in the blood of non-pneumonic subjects lacking pneumococcidal properties and in blood taken before treatment from patients with pneumonia due to the homologous pneumococcus types. In the first portion of this paper the results of studies of the effect of sulfapyridine on the growth curve of pneumococci in artificial media and in human blood are also reported. The immune reactions of the blood of patients with pneumococcus pneumonia before and after treatment with sulfapyridine are reported separately (2).

The action of sulfapyridine on pneumococci in vitro has been studied by various techniques with somewhat conflicting results (3 to 7). McIntosh and Whitby (3) found active multiplication of pneumococci during 6 hours followed by marked bactericidal activity in 24- and 48-hour experiments. The bactericidal activity varied with the size of the inoculum and the concentration of the drug. Fleming, using a "slide-cell" technique with whole and deleukocyted blood, found only bacteriostasis as evidenced by smaller colony size after 24 hours in sulfapyridine-containing blood and as compared with controls. He was able to show bactericidal action only in the presence of leukocytes, and this bactericidal action was enhanced by the addition of specific immune serum. Long, Bliss and Feinstone (5) found sulfapyridine to be somewhat more effective than sulfanilamide as a bacteriostatic agent against Types I, II, and III pneumococci in broth cultures. Reid (6), using Type I pneumococci, found slight bacteriostasis during the logarithmic phase of growth but incomplete bactericidal action later.

Hoyt and Levine (7), using large inocula of Type II pneumococci, found only bacteriostasis in serum and in peptone-free broth in 8 hours' growth. In their experiment, the effect of sulfapyridine was largely lost when peptone was added to a concentration of 2 per cent. McIntosh and Whitby (3) did not find this inhibiting effect of peptone in the action of sulfapyridine on Type I pneumococci. Sulfapyridine was found to have no effect on the immune mechanism in mice. Marked variations have been noted in the sensitiveness of various types and strains of pneumococci to the action of sulfapyridine in vitro and in experimental infections $(8,9)$. Resistance, or "fastness" has been artifically induced by growth in sulfapyridine and this fastness is then found to be independent of virulence and of capsule formation ( 9 , 10).

\section{MATERIALS AND METHODS}

The blood used for the pneumococcidal tests was obtained (1) from normal laboratory workers and hospital patients without recent febrile illness, and (2) from patients with pneumococcus pneumonia before any serum or chemotherapy was started. Only such bloods were employed as lacked pneumococcidal activity or other typespecific antibodies (opsonins, agglutinins and mouse protection) for the types of pneumococci used in the tests. Only homologous types were used in the blood of the pneumonia patients.

The pneumococcidal and phagocytic tests were carried out as in previous studies (1) but with some modifications. The frequency with which considerable numbers of pneumococci were killed off at $\mathbf{4 8}$ hours in tubes which did not exhibit full growth led us to record the number of viable organisms in the tubes showing incomplete growth (that is, the number of colonies in plates poured at 48 hours).

Three-hour test. While these studies were under way, it became apparent that the observation of growth inhibition and pneumococcidal action after 48 hours, as previously carried out, did not distinguish between the 
killing power of the blood itself and that due to the action of the chemical. This could be accomplished, in part, by control tests with inactivated serum and/or "deleukocyted" blood, since either of these conditions interferes with the destruction of pneumococci in the absence of the drug. However, a simpler method was evolved. It was found, by serial colony counts made at frequent intervals, that the pneumococcidal action residing in the blood is most marked during the first few hours of incubation while, as shown by McIntosh and Whitby (3), the action of sulfapyridine becomes apparent only between 2 and 8 hours and sometimes even later. In our own studies, this lag in the action of sulfapyridine lasted at least 4 hours. It was obvious, therefore, that colony counts done early in the test will not only differentiate the two individual activities, but the differences between these and the later ones will reflect more accurately the number of organisms killed through the action of the drug. After a number of experiments in which the inocula and the period of growth were varied, it was found most advantageous to pour plates after 3 hours' incubation from the tube containing blood in which $10^{2}$ and $10^{5}$ pneumococci had been inoculated. In following the course of patients under treatment, this test was of particular value in differentiating between the pneumococcidal activity acquired through the development of immunity and that due to action of the drug. This will be shown in the studies carried out with patients' blood (2).

The pneumococci used in most of the experiments were the stock Types I, III, and V strains in use in this laboratory for a number of years. Type I and Type III strains were originally obtained from the Rockefeller Institute and the Type V strain from the late Georgia Cooper. Their virulence has been maintained by frequent mouse passage. They were grown in rabbit blood broth (beef infusion broth with 1 per cent peptone and 0.05 per cent dextrose, $\mathrm{pH} 7.8$, to which 1 per cent defibrinated rabbit blood is added). All pour plates were made in beef infusion agar, $\mathrm{pH} 7.8$, to which 5 per cent horse blood was added. The pneumococcidal tests were usually done with 3- to 4-hour cultures made with a 50 per cent inoculum, while in the growth curves the cultures used were in the stationary growth phase after 10 hours' growth from a small inoculum. In either case, pour plates of the cultures used yielded between 45 and 120 colonies from $10^{-7}$ cc. For the stock strains, unless otherwise noted, $0.1 \mathrm{cc}$. of this dilution of culture is referred to as having 10 pneumococci. In the case of strains freshly isolated from patients, cultures grew more slowly and more sparsely (10-7 cc. usually yield 10 to 20 colonies).

Growth curves were studied in blood broth and in whole defibrinated blood which lacked pneumococcidal action. When blood was prepared for such tests, the proper amounts of the blood, the culture dilution, and sulfapyridine were introduced into a single tube in proportions corresponding to those used in the pneumococcidal tests. The mixture was then distributed in $0.5 \mathrm{cc}$. amounts in a number of pyrex tubes which were then sealed in an oxygen flame, placed in the incubator and rotated. The tubes were broken open individually at intervals and agar plates poured either with the entire contents or with serial dilutions.

Growth curves in broth were carried out by adding 0.2 cc. of a 10-hour culture to $1.8 \mathrm{cc}$. of the blood broth with or without sulfapyridine and serial decimal dilutions were made in the same medium. The various tubes were then incubated and $0.1 \mathrm{cc}$. amounts were removed at various intervals for culture in agar pour plates, either directly or after proper dilution. Complete bactericidal activity was assumed whenever $0.1 \mathrm{cc}$. of the material yielded no growth. However, in some instances when blood was used, the entire contents of the tube were cultured in rabbit blood broth at the conclusion of the experiment in order to ascertain whether bactericidal action was complete.

Sulfanilamide and sulfapyridine determinations were made by the method of Marshall and Litchfield (11).

The therapeutic serums used were chiefly concentrated horse and rabbit serums furnished for clinical trial by the Lederle Laboratories.

\section{RESULTS}

\section{Effect of sulfapyridine on the growth curve of the pneumococcus}

Stock Type III pneumococcus in blood broth. Control growth curves for this organism are shown in Figure 1. Practically no lag phase was noted, even with small inocula. This absence of lag phase, as will be seen in the figures which follow, was characteristic of the growth of all the strains both in this media and in blood, and occurred with all inocula, irrespective of whether or not sulfapyridine was present (at least in the concentrations used). ${ }^{1}$ The maximum growth without sulfapyridine was attained in about 12 hours with the smaller inocula and as early as 4 hours with the larger inocula. There was a slow decline in population after a stationary phase of 12 to 24 hours.

The effect of sulfapyridine in concentrations of 5 to $10 \mathrm{mgm}$. per $100 \mathrm{cc}$. of the media, is shown in Figures 2 and 3, respectively. Rapid multiplication occurred within the first 4 hours in every instance, even with an initial population of 10 organisms and with a sulfapyridine concentration of $10 \mathrm{mgm}$. per $100 \mathrm{cc}$. The rate of growth in sulfapyridine was about the same as without the drug in this interval. Between 4 and 8 hours

1 This is not strictly true since a more detailed study during the first 4 hours indicates a lag of growth for $11 / 2$ to 2 hours both with and without sulfapyridine. 


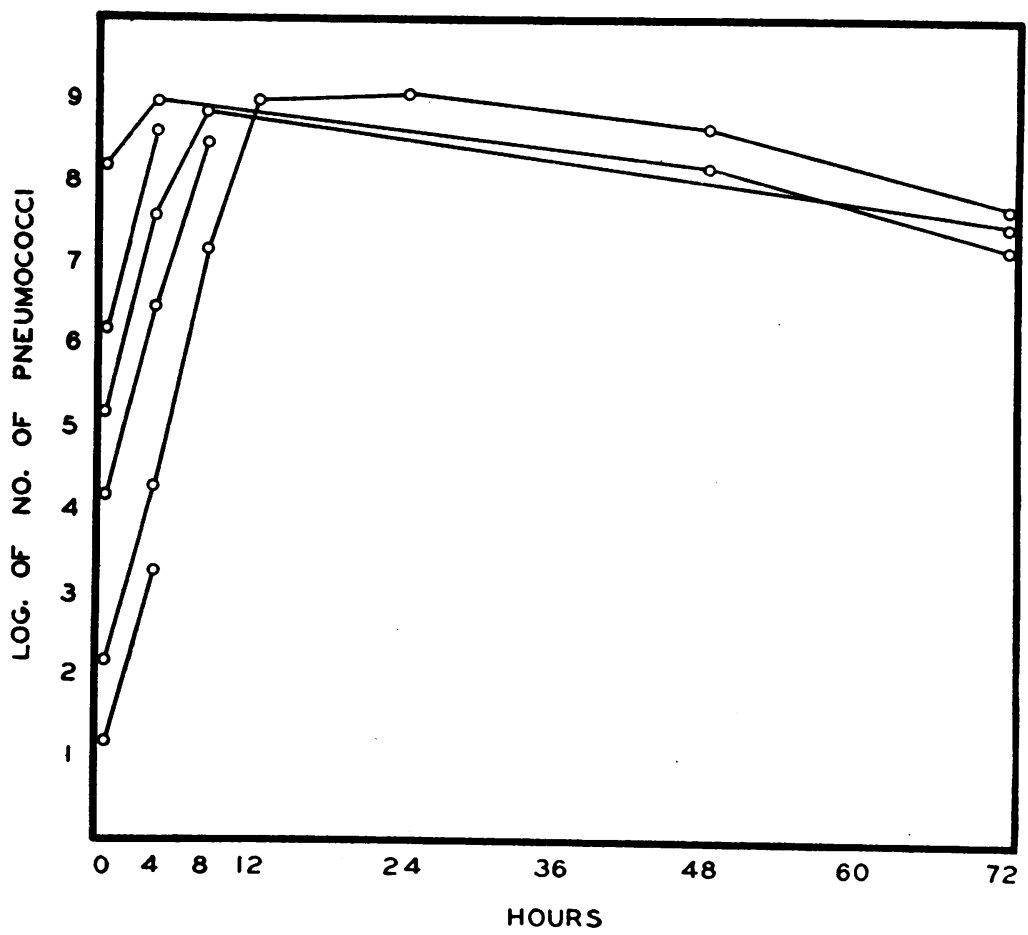

Fig. 1. Growth Curves of Stock Type III Pneumococcus in Broth Without SULFAPYRIDINE

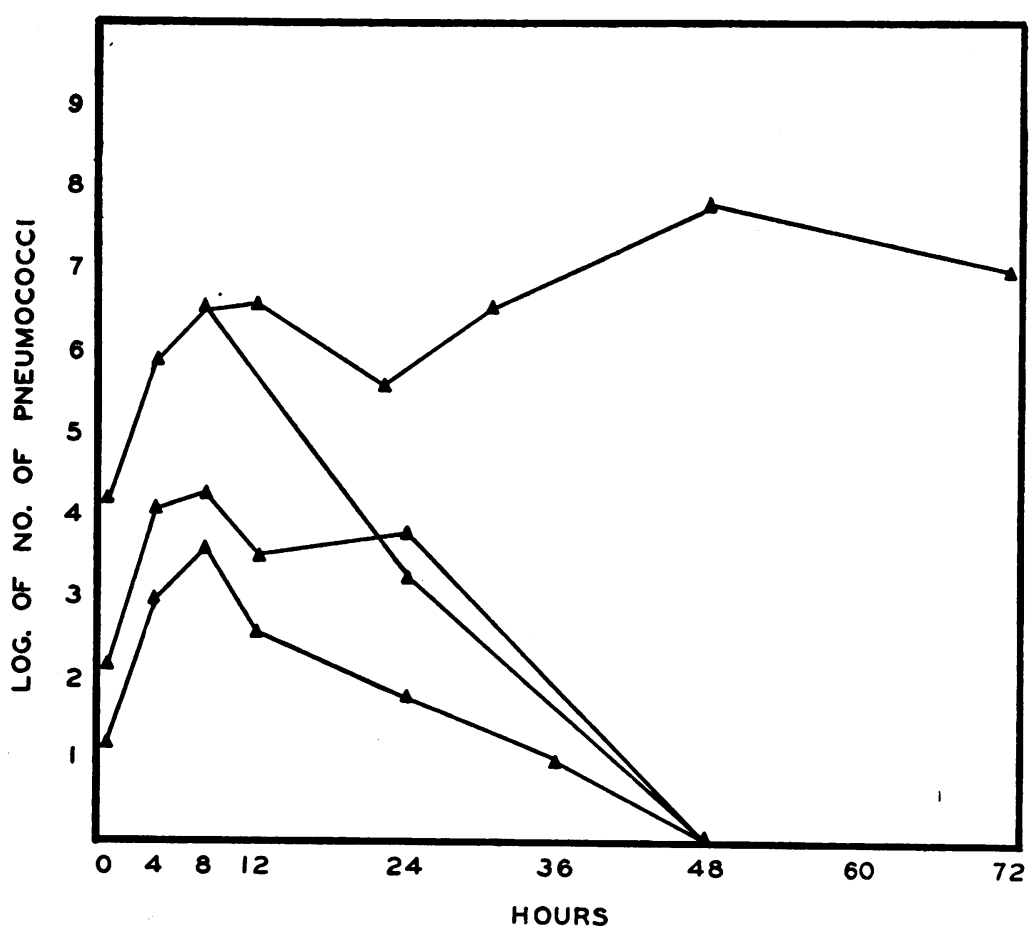

Fig. 2. Growth Curves of Stock Type III Pneumococcus in Broth Containing Sulfapyridine, 5 Mgm. Per 100 cc. 


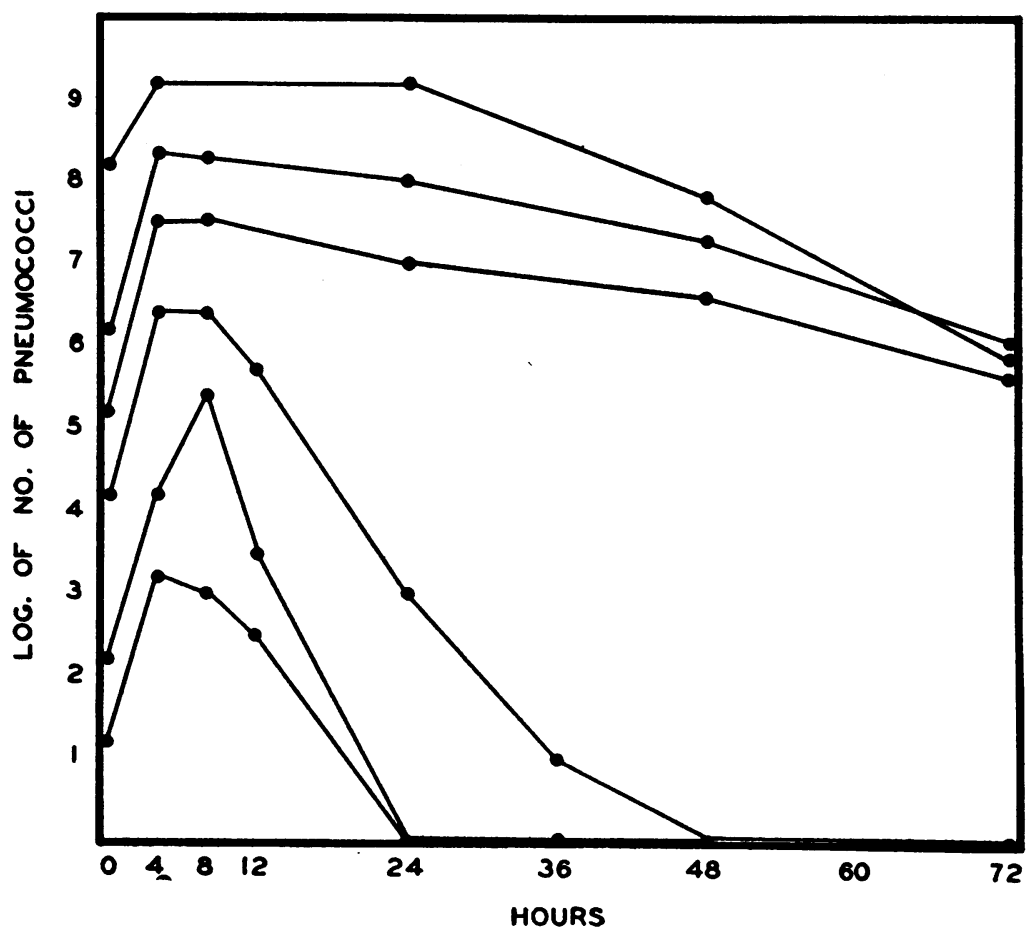

Fig. 3. Growth Curves of Stock Type III Pneumococcus in Broth Containing Sulfapyridine, 10 Mgm. Per 100 cc.

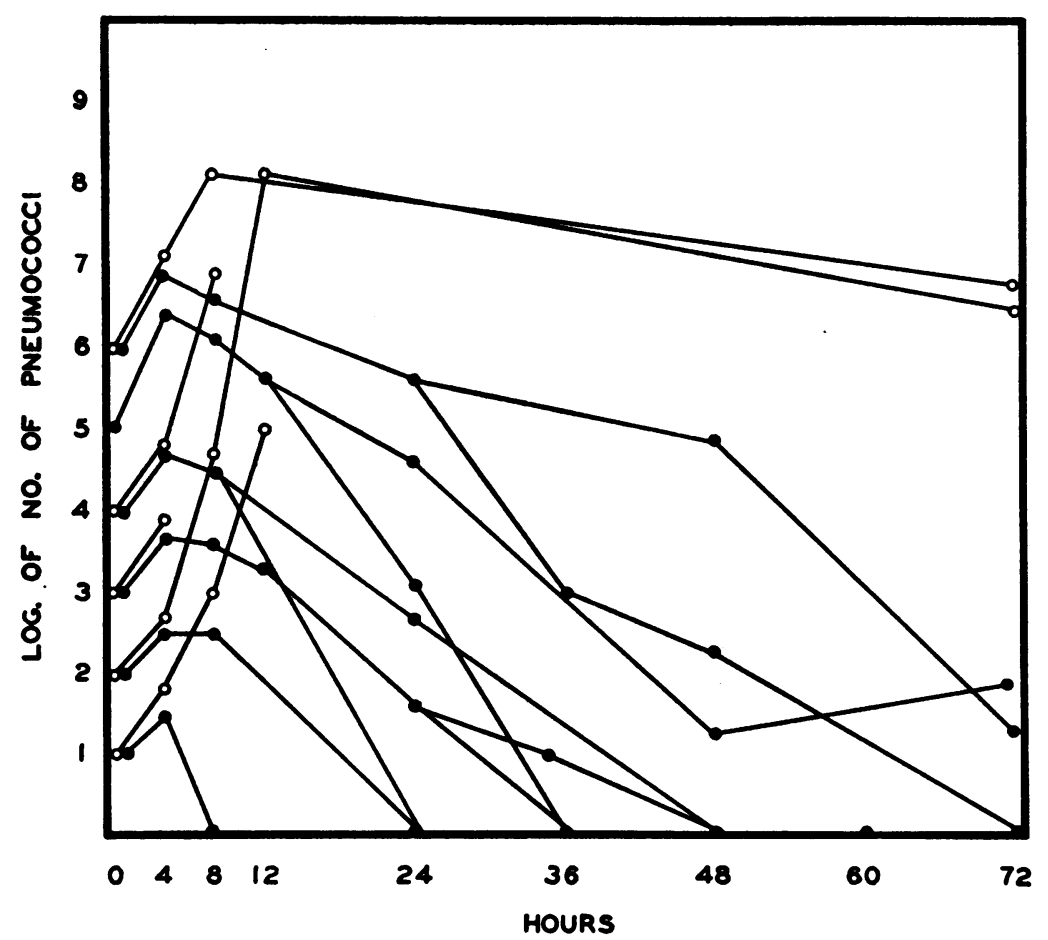

Fig. 4. Growth Curves of Type III Pneumococcus, Strain “Coughlin" IN BRoTH

$$
\begin{aligned}
& O=\text { no sulfapyridine } \\
& Q=\text { sulfapyridine, } 10 \mathrm{mgm} \text {. per } 100 \mathrm{cc} \text {. }
\end{aligned}
$$




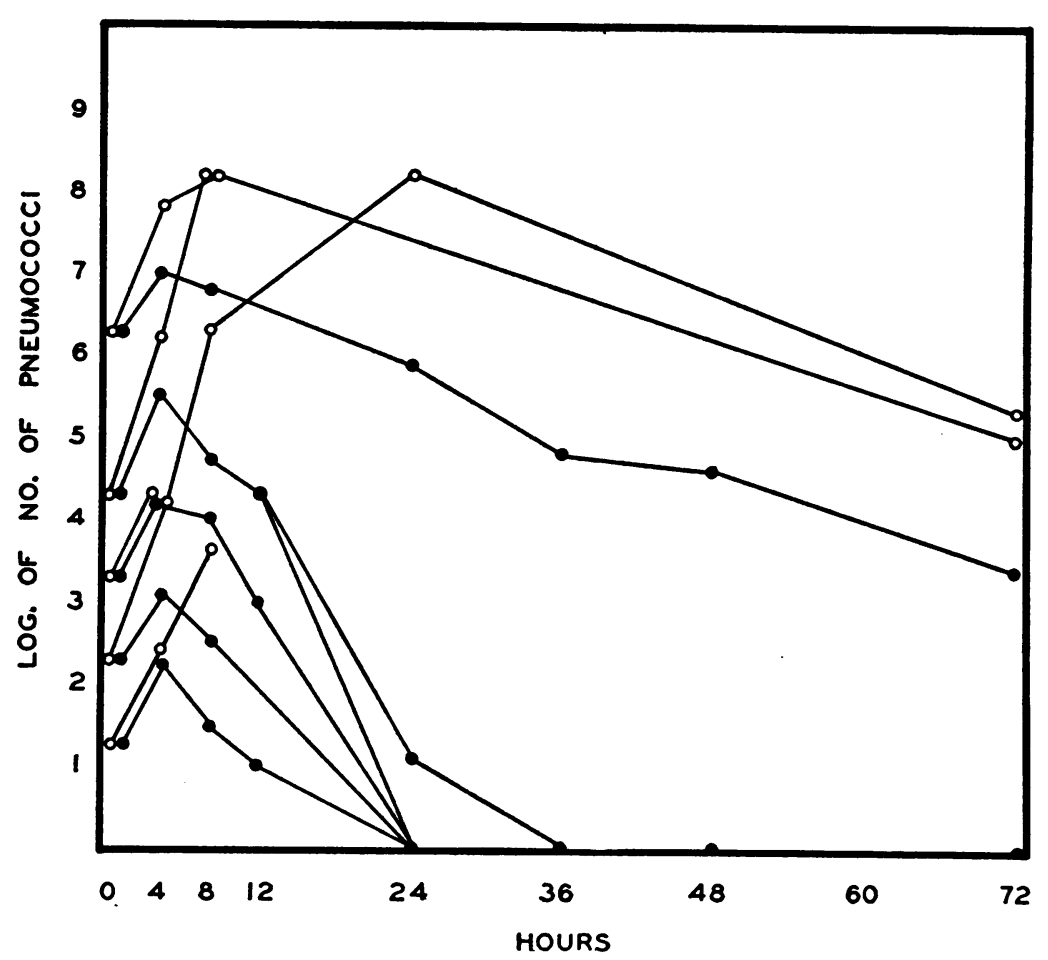

Fig. 5. Growth Curves of Type III Pneumococcus, Strain “Gillyard” IN BRoth

$\mathrm{O}=$ no sulfapyridine

= sulfapyridine, $10 \mathrm{mgm}$. per $100 \mathrm{cc}$.

there was a stationary phase. With a sulfapyridine concentration of $5 \mathrm{mgm}$. per cent and an initial population of $10^{5}$ pneumococci or more, growth occurred at about the same rate as in the controls. With smaller inocula in this concentration of the drug there was a steady decline in the number of viable organisms after the stationary period, and none could be grown after 48 hours. In one experiment, slow growth continued up to 48 hours with an inoculum of $10^{4}$ organisms (Figure 2). With a sulfapyridine concentration of $10 \mathrm{mgm}$. per cent, there was a more rapid decline in the number of viable organisms so that none could be recovered at the end of 24 hours when 10 or 100 organisms were inoculated. With an original inoculum of $10^{4}$ diplococci there were less than 10 viable organisms per cc. after 36 hours, and none after 48 hours.

Growth curves of 3 different strains of Type III pneumococcus were studied in rabbit blood broth with and without $10 \mathrm{mgm}$. of sulfapyridine per 100 cc. Strain "Coughlin" (Figure 4) was obtained from a blood culture, and strains " Gillyard" (Figure 5) and "Taylor" (Figure 6) were isolated from sputum. Each strain was obtained before treatment with sulfapyridine was begun. All 3 patients recovered after treatment although the first had a very protracted illness. Taylor had a mild atypical pneumonia, but 1 year previously he had had a severe attack of Type III pneumococcic lobar pneumonia from which he had made a rapid recovery following specific serum therapy.

There were some differences noted in the growth curve of each of these 3 strains and, in some instances, considerable variations were noted when the same tests were repeated. Some of the latter variations are indicated in the figures. In general, these 3 strains grew somewhat more slowly, and the maximum growth showed considerably fewer viable organisms than in the case of the stock Type III strain. All exhibited rapid growth during the first 4 hours, irrespective of the size of the inoculum. In the media containing 


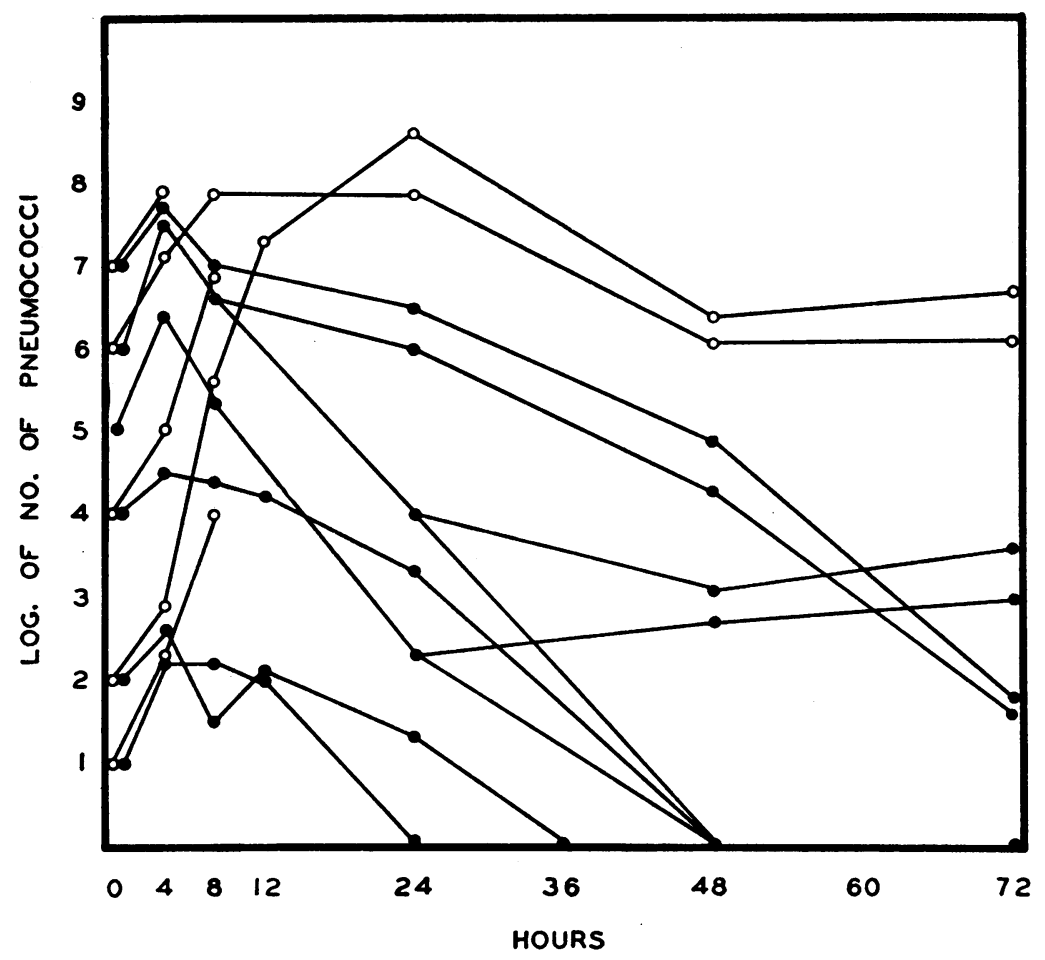

Fig. 6. Growth Curves of Type III Pneumococcus, Strain “Taylor” IN BROTH

$\mathrm{O}=$ no sulfapyridine

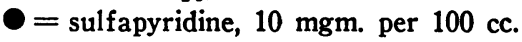

$10 \mathrm{mgm}$. of sulfapyridine per $100 \mathrm{cc} .$, killing was complete with inocula of $10^{4}$ pneumococci or less in the case of the Coughlin and Gillyard strains. Incubation for 36 to 48 hours was necessary to accomplish this in some of the tests which started with $10^{3}$ and $10^{4}$ diplococci. With larger inocula there was growth inhibition with a slower decline in the number of viable organisms after 4 to 8 hours.

Stock Type I and Type $V$ strains. The growth curves for these organisms in blood broth media with and without sulfapyridine $10 \mathrm{mgm}$. per 100 cc. are shown in Figures 7 and 8, respectively. For the most part, the curves for both these strains were similar to those obtained with the stock Type III pneumococcus. The decline in the number of viable organisms began after 4 hours' growth with most inocula up to $10^{6}$ organisms in the case of the Type I pneumococcus, whereas with the Type $\mathrm{V}$ strain this decline apparently began after 8 hours.
Stock Type III strain in defibrinated human blood. The blood used was from a patient without infection. Repeated tests showed free growth of Type III pneumococci in this blood even with the smallest inocula. Growth curves were carried out several times without sulfapyridine and with 5 and $10 \mathrm{mgm}$. per cent of this drug. The control curves were all similar to those already shown for this organism in rabbit blood broth, except that a greater final population was attained in the blood. The curves with sulfapyridine 10 mgm. per cent and small original inocula all showed the typical rise and rapid fall, killing being complete in 24 hours. With the drug in a concentration of $5 \mathrm{mgm}$. per cent, growth occurred in varying degrees with an inoculum of 10 diplococci per cc., after which the number of viable organisms remained more or less static for 48 hours or more. A few representative curves are shown in Figure 9. 


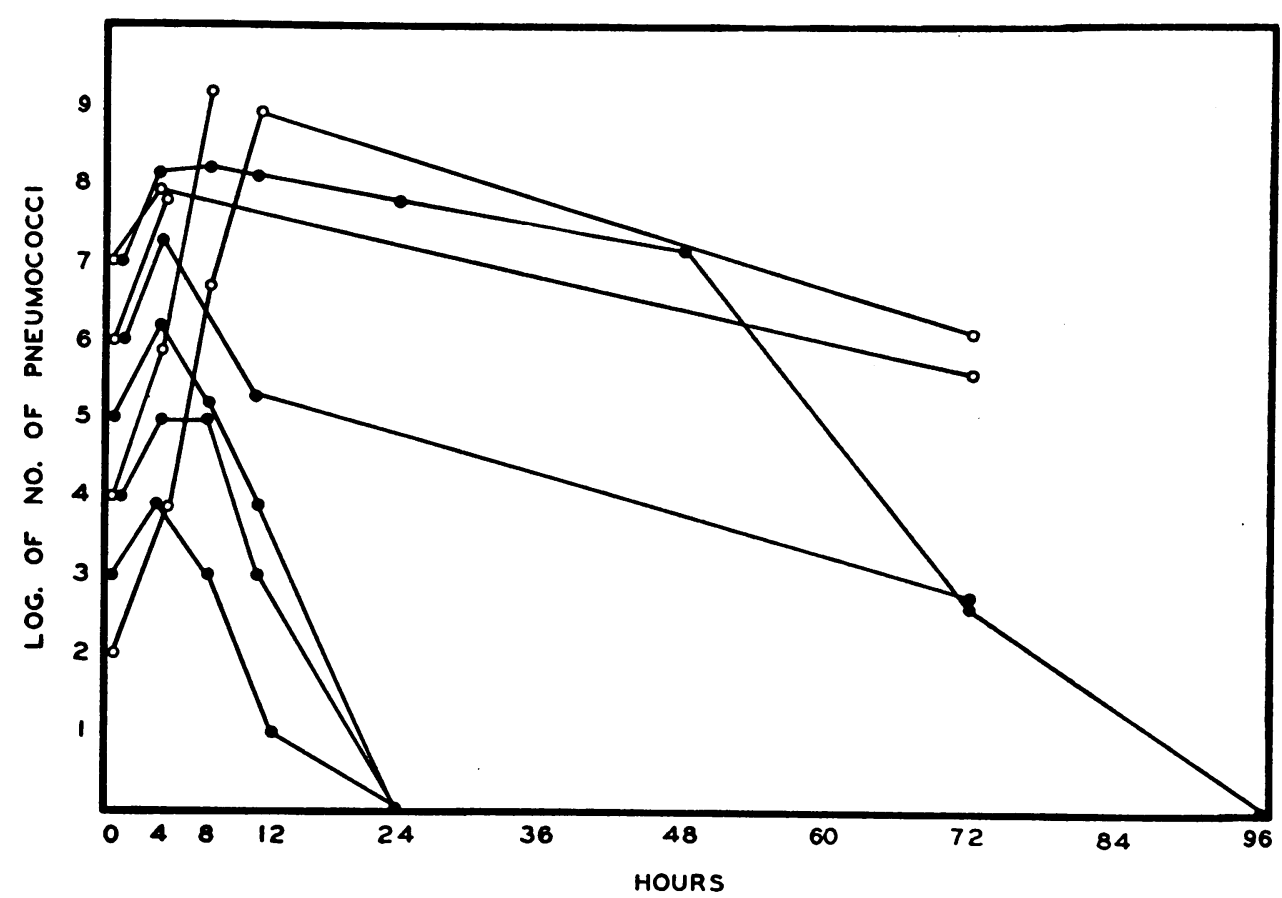

Fig. 7. Growth Curves of Stock Type I Pneumococcus in Broth $\mathrm{O}=$ no sulfapyridine

$\bullet=$ sulfapyridine, $10 \mathrm{mgm}$. per $100 \mathrm{cc}$.

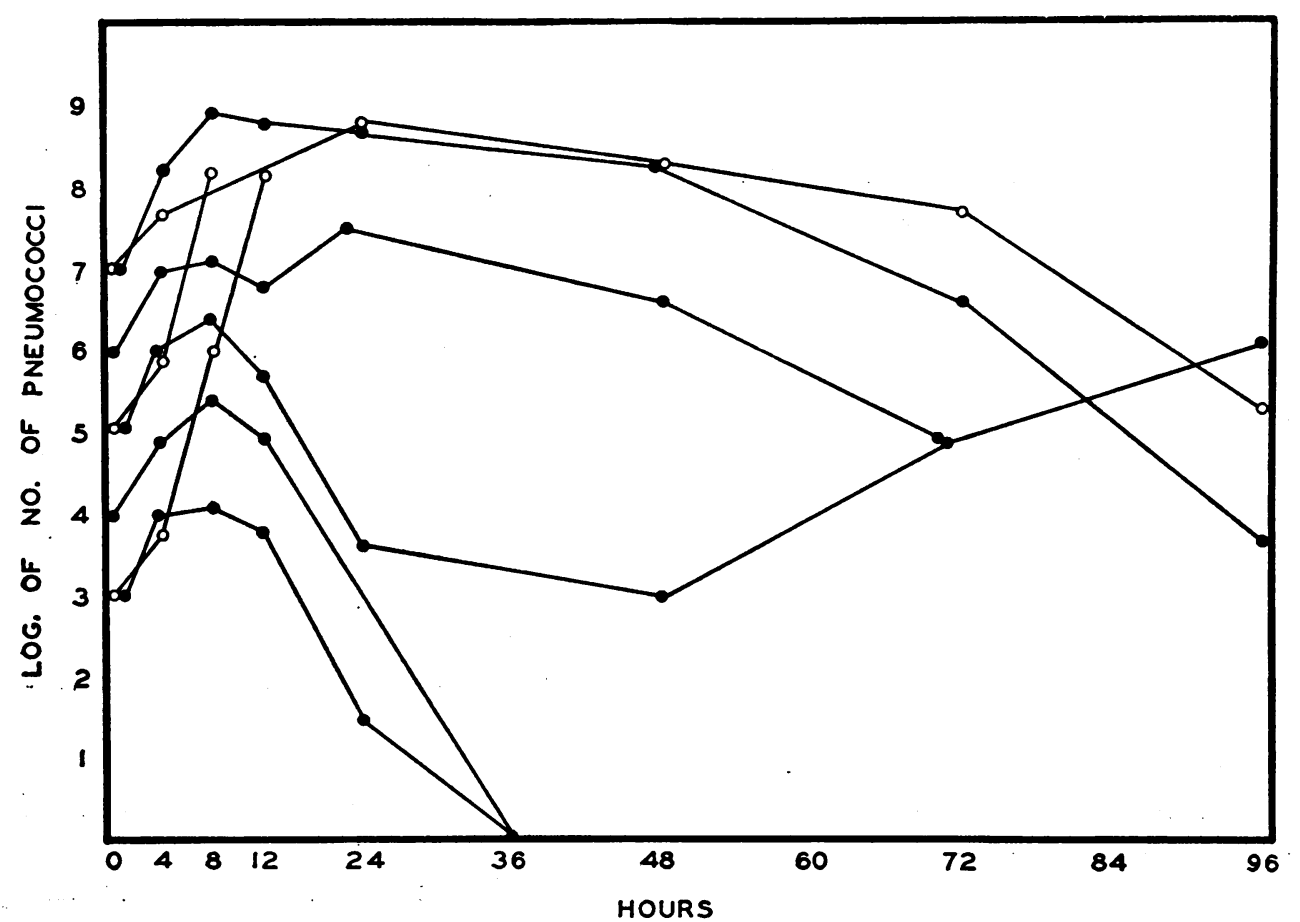

Fig. 8. Growth Curves of Stock Type V Pneumococcus in Broth $\mathrm{O}=$ no sulfapyridine

0 = sulfapyridine, $10 \mathrm{mgm}$. per $100 \mathrm{cc}$. 


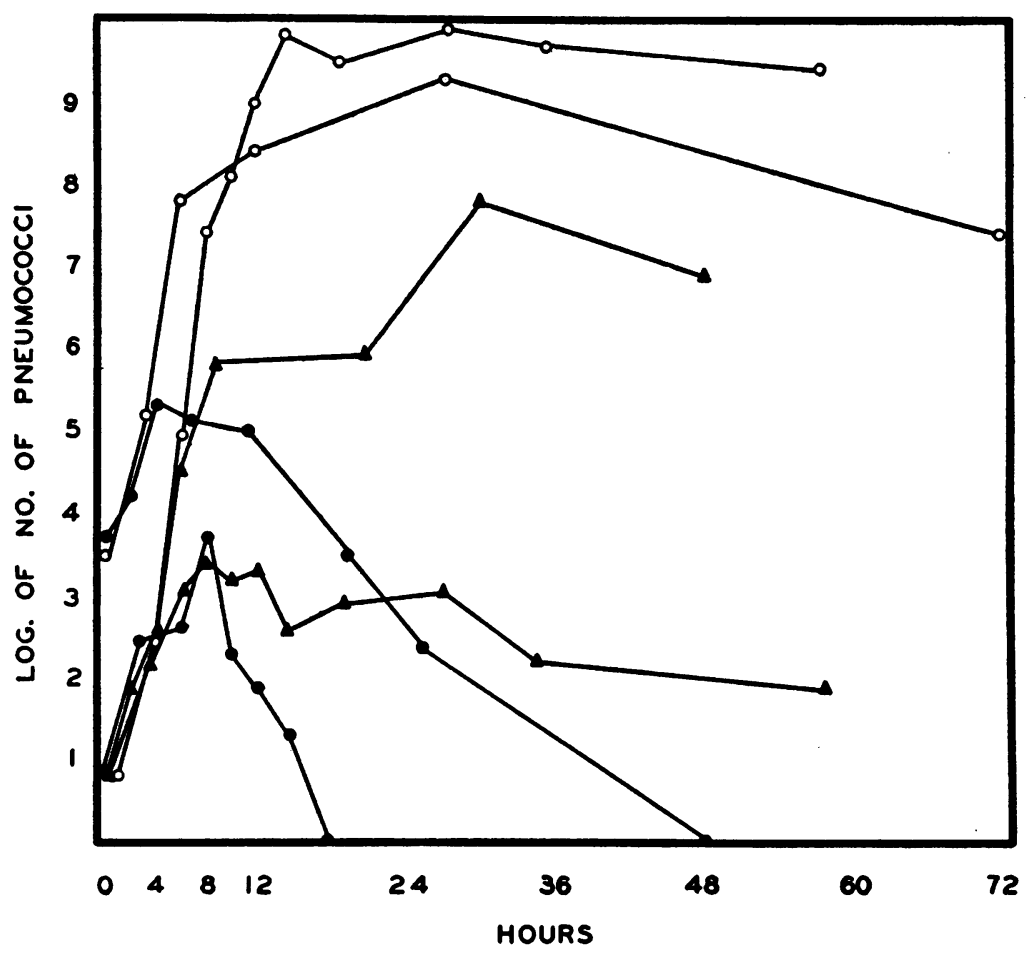

Fig. 9. Growth Curves of Stock Type III Pneumococcus in Defibrinated Human BLOOD

$\mathrm{O}=$ no sulfapyridine

$\Delta=$ sulfapyridine $5 \mathrm{mgm}$. per $100 \mathrm{cc}$.

= sulfapyridine $10 \mathrm{mgm}$. per $100 \mathrm{cc}$.

Effect of certain environmental factors on the growth curve of Type III pneumococcus

Effect of exposure to a temperature of $5^{\circ} \mathrm{C}$. Blood broth cultures were inoculated with various numbers of pneumococci and exposed to a temperature of about $5^{\circ} \mathrm{C}$. for periods of 4 to 72 hours either immediately after inoculation or after 4 hours' growth. Further incubation at $37^{\circ} \mathrm{C}$. was resumed in most instances after this exposure to cold. The resulting growth curves with and without sulfapyridine are shown in Figures 10 and 11 , respectively. The exposure to $5^{\circ} \mathrm{C}$. resulted in a fairly static population for the duration of this exposure. After reincubation at $37^{\circ}$ C., the resulting growth curve was essentially the same as though no exposure to cold had taken place.

Growth at $27^{\circ} \mathrm{C}$. Growth curves carried out at this temperature with and without sulfapyridine $10 \mathrm{mgm}$. per cent showed a lag phase of several hours' duration. The subsequent multiplication was considerably slower than at $37^{\circ} \mathrm{C}$. The effect of sulfapyridine, however, was the same as at $37^{\circ}$ C. Bacteriostasis occurred with the large inocula and killing was complete when a small inoculum was used. There was a longer stationary phase after multiplication occurred, but the rate of decline in population was rapid in the cultures that started with a small inoculum.

Growth at $40^{\circ} \mathrm{C}$. The stock Type III strain used is not a heat labile strain (12) and growth without sulfapyridine was essentially the same at approximately $40^{\circ} \mathrm{C}$. as at $37^{\circ} \mathrm{C}$. during a 48 -hour period. With sulfapyridine $10 \mathrm{mgm}$. per cent, the effect was the same as at $37^{\circ} \mathrm{C}$. during the first 48 hours. After that time there was a decline in population in the control cultures, but a more rapid decline occurred in those containing sulfapyridine.

Effect of 2 per cent peptone. The media used throughout contained 1 per cent peptone. The 


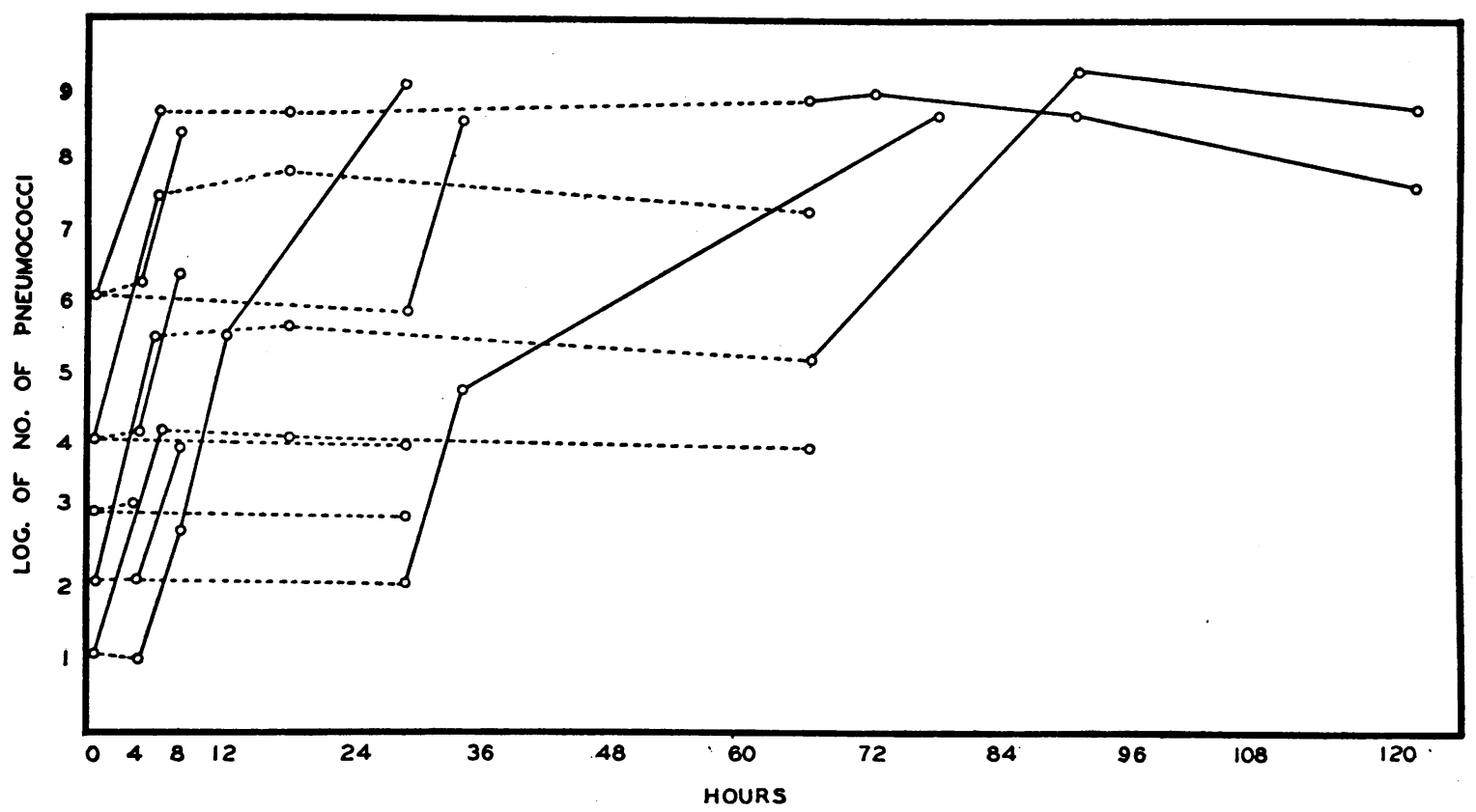

Fig. 10. Growth Curve of Stock Type III Pneumococcus in Broth without Sulfapyridine Solid line $=$ growth at $37^{\circ} \mathrm{C}$.

Broken line $=$ in ice box at $5^{\circ} \mathrm{C}$.

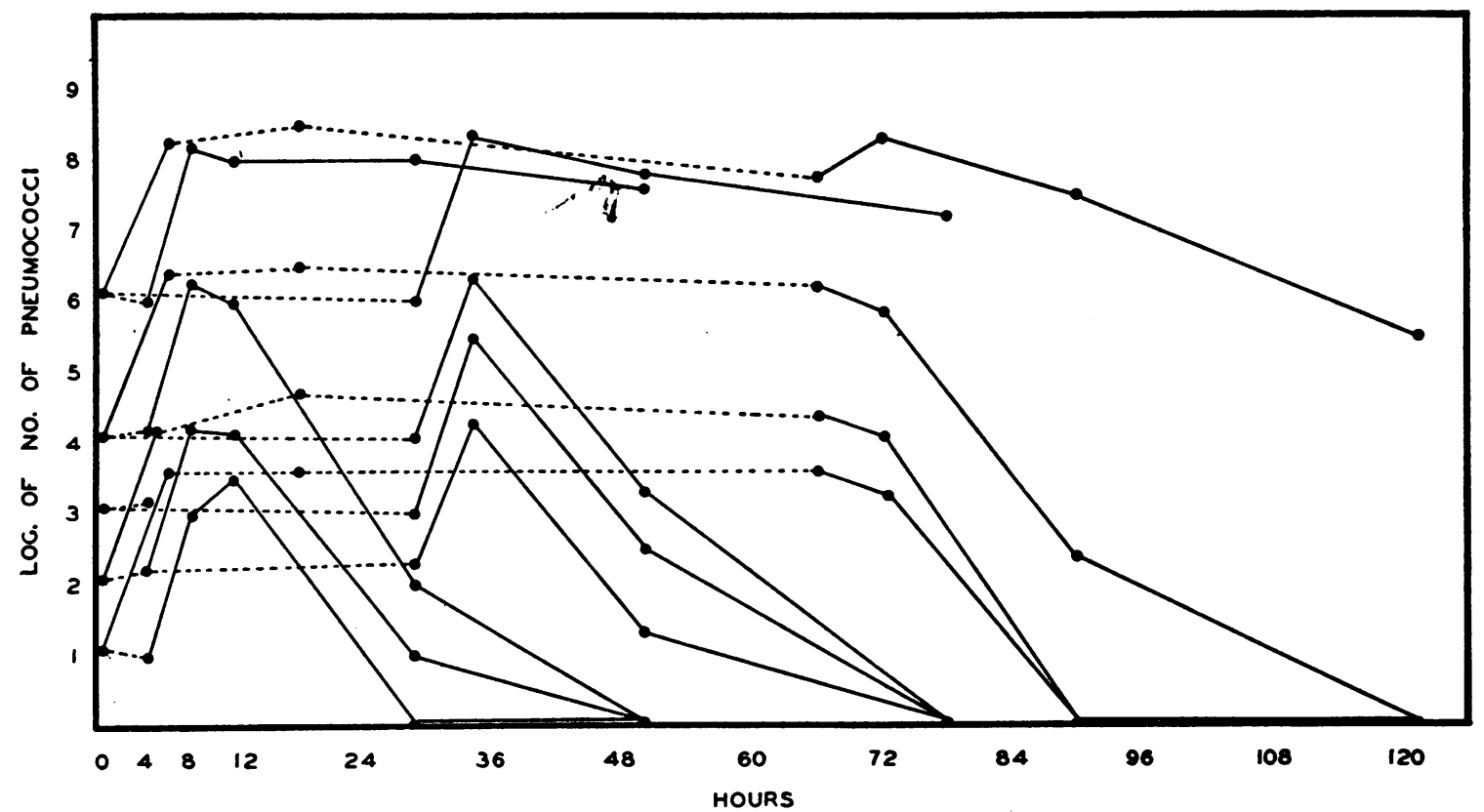

Fig. 11. Growth Curve of Stock Type III Pneumococcus in Broth with Sulfapyridine 10 Mgm. Per $100 \mathrm{cc}$.

Solid line $=$ growth at $37^{\circ} \mathrm{C}$.

Broken line $=$ in ice box at $5^{\circ} \mathrm{C}$. 
TABLE I

The in vitro action of sulfanilamide, sulfapyridine, and homologous immune rabbit serum on pneumococci in fresh defibrinated blood lacking preumococcidal activity

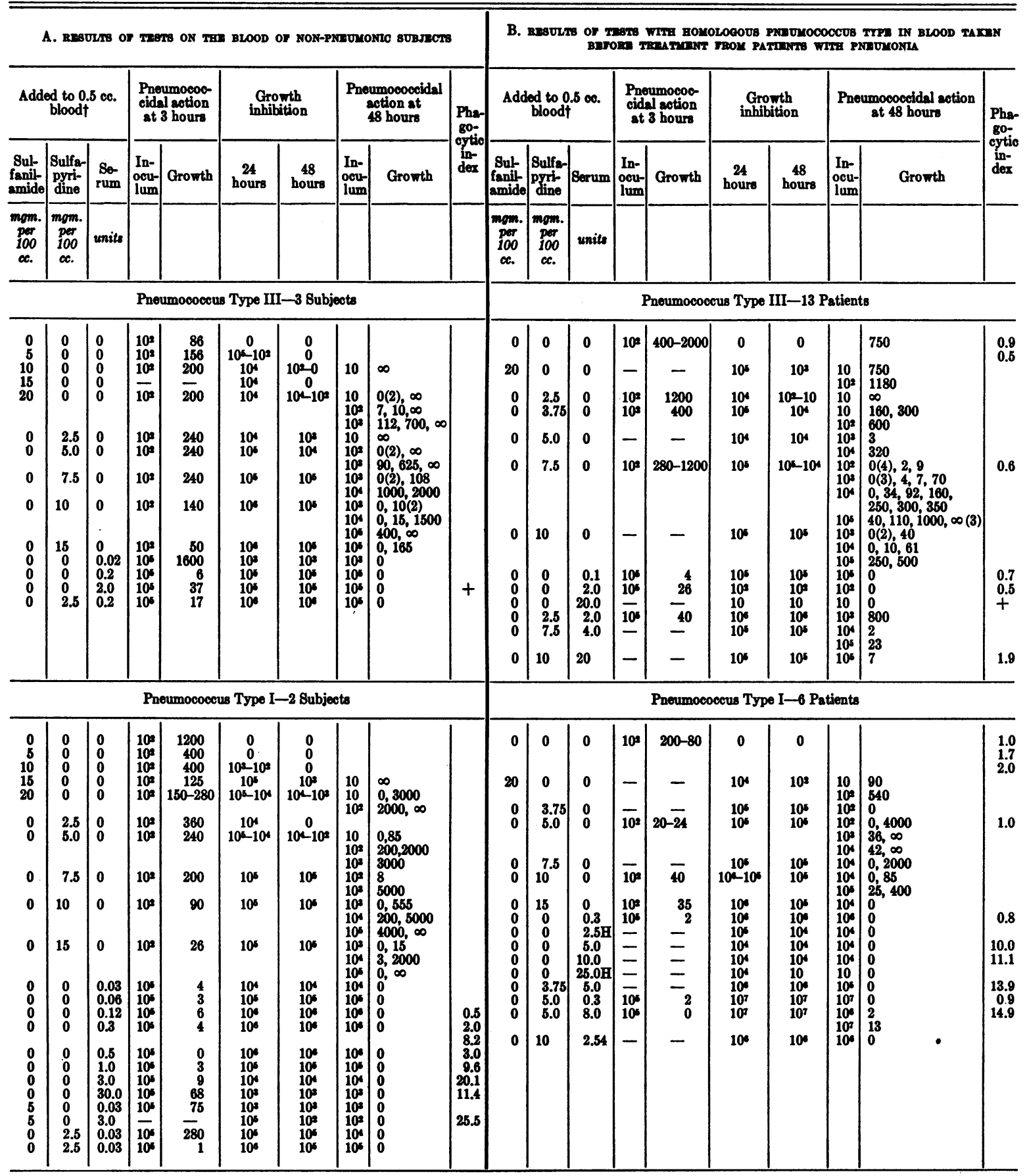


TABLE I-Continued

\begin{tabular}{|c|c|c|c|c|c|c|c|c|c|c|c|c|c|c|c|c|c|c|c|}
\hline \multicolumn{10}{|c|}{ A. EDSOLNS OF TESTS ON THE BLOOD OF NON-PNEUYONIC BUBJECTS } & \multicolumn{10}{|c|}{ 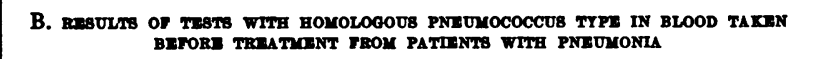 } \\
\hline \multicolumn{3}{|c|}{$\begin{array}{c}\text { Added to } 0.5 \text { ce. } \\
\text { blood } \dagger\end{array}$} & \multicolumn{2}{|c|}{$\begin{array}{l}\text { Pneumococ } \\
\text { cidal action } \\
\text { at } 3 \text { hours }\end{array}$} & \multicolumn{2}{|c|}{$\begin{array}{l}\text { Growth } \\
\text { inhibition }\end{array}$} & \multicolumn{2}{|c|}{$\begin{array}{c}\text { Pneumococcidal } \\
\text { action at } \\
48 \text { hours }\end{array}$} & \multirow{2}{*}{$\begin{array}{l}\text { Pha- } \\
\text { go- } \\
\text { oytic } \\
\text { in- } \\
\text { dex }\end{array}$} & \multicolumn{3}{|c|}{$\begin{array}{l}\text { Added to } 0.5 \mathrm{cc} . \\
\text { blood } t\end{array}$} & \multicolumn{2}{|c|}{$\begin{array}{l}\text { Pneumococ- } \\
\text { cidal action } \\
\text { at } 3 \text { hours }\end{array}$} & \multicolumn{2}{|c|}{$\begin{array}{c}\text { Growth } \\
\text { inhibition }\end{array}$} & \multicolumn{2}{|c|}{$\begin{array}{l}\text { Pneumococcidal action } \\
\text { at } 48 \text { hours }\end{array}$} & \multirow{2}{*}{$\begin{array}{l}\text { Pha- } \\
\text { go- } \\
\text { cytic } \\
\text { in- } \\
\text { dex }\end{array}$} \\
\hline $\begin{array}{l}\text { Sul- } \\
\text { fanil- } \\
\text { amide }\end{array}$ & $\begin{array}{c}\text { Sulfa- } \\
\text { pyri- } \\
\text { dine }\end{array}$ & So- & $\begin{array}{l}\text { In- } \\
\text { ocu- } \\
\text { lum }\end{array}$ & Growth & $\stackrel{24}{\text { hours }}$ & $\begin{array}{c}48 \\
\text { hours }\end{array}$ & $\begin{array}{l}\text { In- } \\
\text { ocu- } \\
\text { lum }\end{array}$ & Growth & & $\begin{array}{l}\text { Sul- } \\
\text { fanil- } \\
\text { amide }\end{array}$ & $\begin{array}{c}\text { Sulfa- } \\
\text { pyri- } \\
\text { dine }\end{array}$ & Serum & $\begin{array}{l}\text { In- } \\
\text { oeu- } \\
\text { lum }\end{array}$ & Growth & $\begin{array}{c}24 \\
\text { hours }\end{array}$ & $\begin{array}{c}48 \\
\text { hours }\end{array}$ & $\begin{array}{l}\text { In- } \\
\text { ocu- } \\
\text { lum }\end{array}$ & Growth & \\
\hline $\begin{array}{c}\text { mom. } \\
\text { per } \\
100 \\
\text { ce. }\end{array}$ & $\begin{array}{c}\text { mom. } \\
\text { per } \\
100 \\
\text { cc. }\end{array}$ & units & & & & & & & & $\begin{array}{c}\text { mom. } \\
\text { per } \\
100 \\
c c .\end{array}$ & $\begin{array}{c}\text { mom. } \\
\text { per } \\
100 \\
\propto .\end{array}$ & units & & & & & & & \\
\hline \multicolumn{10}{|c|}{ Pneumococcus Type V-1 Subject } & \multicolumn{10}{|c|}{ Pneumococcus Type V-3 Patients } \\
\hline $\begin{array}{r}0 \\
10 \\
20 \\
0 \\
0 \\
0 \\
0 \\
0 \\
0 \\
0 \\
10 \\
0\end{array}$ & $\begin{array}{l}\mathbf{0} \\
0 \\
0 \\
2.5 \\
5.0 \\
10 \\
15 \\
0 \\
0 \\
0 \\
0 \\
2.5\end{array}$ & $\begin{array}{l}0 \\
0 \\
0 \\
0 \\
0 \\
0 \\
0 \\
0.04 \\
0.4 \\
4.0 \\
0.04 \\
0.04\end{array}$ & $\begin{array}{l}10^{2} \\
10^{2} \\
10^{2} \\
10^{2} \\
10^{2} \\
10^{2} \\
10^{2} \\
10^{5} \\
10^{5} \\
10^{5} \\
10^{5} \\
10^{5}\end{array}$ & $\begin{array}{r}600 \\
500 \\
1000 \\
800 \\
1200 \\
600 \\
600 \\
17 \\
51 \\
200 \\
28 \\
61\end{array}$ & $\begin{array}{c}0 \\
10 \\
10^{4} \\
10^{2} \\
10^{4} \\
10^{5} \\
10^{6} \\
10^{3} \\
10^{3} \\
10^{2} \\
10^{5} \\
10^{5}\end{array}$ & $\begin{array}{c}0 \\
0 \\
10^{3} \\
0 \\
10^{2} \\
10^{5} \\
10^{5} \\
10^{3} \\
10^{3} \\
10^{2} \\
10^{4} \\
10^{3}\end{array}$ & $\begin{array}{l}10^{2} \\
10^{2} \\
10^{4} \\
10^{5} \\
10^{3} \\
10^{3} \\
10^{2} \\
10^{3} \\
10^{2}\end{array}$ & $\begin{array}{l}0 \\
0 \\
0 \\
0 \\
0 \\
0 \\
0 \\
0 \\
0\end{array}$ & $\begin{array}{c}0.5 \\
15.9 \\
+ \\
0.6 \\
0.8\end{array}$ & $\begin{array}{r}0 \\
10 \\
100 \\
0 \\
0 \\
0 \\
0 \\
0 \\
0 \\
0 \\
0 \\
0 \\
0\end{array}$ & \begin{tabular}{|l|}
0 \\
0 \\
0 \\
2.5 \\
3.75 \\
5.0 \\
7.5 \\
10 \\
15 \\
0 \\
0 \\
2.5 \\
3.75
\end{tabular} & $\begin{array}{l}0 \\
0 \\
0 \\
0 \\
0 \\
0 \\
0 \\
0 \\
0 \\
0.4 \\
4.0 \\
4.0 \\
0.4\end{array}$ & $\begin{array}{l}10^{2} \\
10^{3} \\
10 \\
10 \\
10^{2} \\
10 \\
\frac{10}{10} \\
10^{2} \\
10^{5} \\
10^{4} \\
10^{5}\end{array}$ & $\begin{array}{r}25-150 \\
200 \\
25 \\
25 \\
600 \\
25 \\
-25 \\
240 \\
22 \\
80 \\
30 \\
23\end{array}$ & $\begin{array}{l}0 \\
10^{2} \\
10^{4} \\
10^{3} \\
10^{4} \\
10^{4} \\
10^{6} \\
10^{4} \\
10^{6} \\
10^{6} \\
10^{4} \\
10^{6} \\
10^{7}\end{array}$ & $\begin{array}{l}0 \\
0 \\
104 \\
10 \\
10^{4} \\
10^{4} \\
10^{5} \\
10^{4} \\
10^{5} \\
10^{6} \\
10^{2} \\
10^{5} \\
10^{5}\end{array}$ & $\begin{array}{l}10^{4} \\
10 \\
10^{3} \\
10^{3} \\
10^{5} \\
10^{4} \\
10^{5} \\
10^{5} \\
10^{5} \\
10^{5} \\
10^{5} \\
10^{5}\end{array}$ & $\begin{array}{l}0 \\
0 \\
5 \\
97 \\
0 \\
17 \\
5 \\
0 \\
0 \\
20 \\
5 \\
3\end{array}$ & $\begin{array}{r}1.5 \\
0.6 \\
0.6 \\
0.5 \\
0.9 \\
5.2 \\
12.6 \\
6.8 \\
7.6\end{array}$ \\
\hline
\end{tabular}

Explanation: † All added materials were contained in $0.1 \mathrm{cc}$. saline. The figures represent the final concentration. $\mathrm{H}=$ Immune horse serum; when not designated, rabbit serum was used. $-=$ Test not done.

Pneumococcidal action: In the 3-hour test, except in some of the pneumonia patients, only $10^{2}$ and $10^{5}$ pneumococci were inoculated and agar pour plates were made after 3 hours' incubation. The numbers listed under "growth" indicate pneumococcus colonies in the pour plates. $\infty=$ too numerous to count. Smaller inocula than the ones listed showed no growth. With larger inocula the number of colonies were too numerous to count. Numbers in parentheses indicate the number of tests in which the same results were obtained. The result of each test is listed.

Growth inhibition: The figures represent the largest inocula showing no color change after incubation, or the extremes of the results of multiple tests.

Phagocytic index: Average number of pneumococci per polymorphonuclear leukocyte. $+=$ Clumping of organisms and leukocytes preventing accurate count. When not listed, the phagocytic index was under 0.5 .

difference between the growth curves using this medium and those made with defibrinated blood did not indicate any striking inhibitory effect of the peptone on the action of sulfapyridine. This can be seen from a comparison of Figures 2 and 3 with Figure 9. Further growth curves with the same broth containing 2 per cent peptone and sulfapyridine $10 \mathrm{mgm}$. per $100 \mathrm{cc}$. were almost identical with those obtained with the 1 per cent peptone broth used routinely.

\section{Action of sulfapyridine, sulfanilamide, and im- mune serum on pneumococci in fresh defibrinated human blood}

Pnuemococcidal tests were done with Types I, III, and V pneumococci in the blood of nonpneumonic subjects and also in the blood taken before treatment from patients with pneumonia due to the homologous type of pneumococcus. Varying amounts of the drug and of homologous immune serum were used. None of the bloods employed in these tests showed any pneumococcidal action for the organisms used without the addition of these chemicals or serum.

The results shown in Table I clearly indicate the difference between the pneumococcidal action resulting from the immune mechanism and that due to the effects of the drugs. In the 3-hour tests, there is no reduction in the number of viable organisms except in the presence of immune serum. Furthermore, the end-point in the pneumococcidal tests as conducted was quite sharp when immune serum was present, killing being complete at 48 hours with one of the decimal dilutions of culture, while full growth occurred with the next higher dilution during this period. With the drugs, on the other hand, varying degrees of bacteriostasis and killing occurred with more than one of the dilutions of culture in which full growth did not occur. 
As previously shown for the Type III pneumococcus (1), sulfanilamide exerted some bacteriostatic action with concentrations below 10 mgm. per $100 \mathrm{cc}$. of blood. With higher concentrations, this bacteriostasis is more marked and some bactericidal activity may occur. Each of the 3 types tested behaved similarly in this respect.

Sulfapyridine was considerably more effective than sulfanilamide in each instance. Bacteriostasis was noted with large inocula, and small numbers of organisms were killed in 48 hours in the presence of sulfapyridine in a concentration of $5 \mathrm{mgm}$. per $100 \mathrm{cc}$. Concentrations of $10 \mathrm{mgm}$. per cent resulted in complete killing of $10^{4}$ pneumococci and there was a marked reduction in the number of viable organisms with larger inocula.

As previously shown by Ward $(13,14)$, the addition of immune serum resulted in considerable pneumococcidal action, the degree varying with the amount of antibody added. It is of interest to note that definite pneumococcidal action occurred with considerably lower concentrations than those required to induce phagocytosis by the method employed here.

In a number of tests, the smallest effective quantity of serum was combined with small amounts of sulfanilamide or sulfapyridine. The effect on the pneumococcidal action of the blood was equivalent to a summation of the effects of each of these agents used separately.

The tests carried out in the blood obtained before treatment from patients with pneumococcic pneumonia gave results essentially similar to those obtained with the blood of the non-pneumonic subjects.

In Table $I$, the number of viable organisms present after 48 hours' incubation are recorded in detail. Where several tests were done with the same combination of materials, the results indicate the variations observed in different bloods. These data reflect clearly the inhibitory and bactericidal action of sulfapyridine.

The tests carried out with blood taken from patients after treatment gave similar results, corresponding to the concentration of antibodies and sulfapyridine present at the time. Where 3-hour tests were carried out in blood taken after treatment with sulfapyridine and no reduction in number of pneumococci was found at that time, the final results were the same as those obtained with drug added to the original blood taken before treatment. These results are reported separately (2).

Effect of soluble. specific substance. Since homologous type-specific soluble substance is known to inhibit the pneumococcidal action both of normal and of immune serum (14), it was of interest to see whether it would also interfere with the pneumococcidal action of sulfapyridine. This was tested in the blood of a heavily infected patient with Type III pneumococcic pneumonia taken before treatment was begun and again after sulfapyridine therapy. The results of these tests are shown in Table II. The 3-hour tests indicated rapid killing of large numbers of added pneumococci in the presence of immune serum. This pneumococcidal action of immune serum was inhibited in the presence of soluble-specific substance added in the form of a filtrate from a culture of the homologous pneumococcus. This neutralizing effect of the culture filtrate on the action of immune serum was evident even in the presence of sulfapyridine, since no killing occurred in 3 hours. The growth inhibition and pneumococcidal action of the sulfapyridine, however, was not affected by the soluble-specific substance, as shown by the inhibition and killing at 48 hours.

\section{DISCUSSION}

The various growth curves indicate that, under the conditions of these experiments, growth of pneumococci occurred in the presence of concentrations of sulfapyridine up to $10 \mathrm{mgm}$. per 100 cc. in the same manner as in control media containing no sulfapyridine for an initial period of 4 hours or longer. During this early period there was usually no appreciable lag phase and the same logarithmic rate of growth occurred with sulfapyridine as without it. The growth phase was usually followed by a phase of stationary growth and then a period of maximum sulfapyridine effect. The rate of growth during the initial period, whether or not a stationary phase followed, and the duration of the latter when it occurred, seemed to depend on the strain used. The early growth phase was also longer at $27^{\circ} \mathrm{C}$. than at $37^{\circ} \mathrm{C}$. Whether bacteriostasis or killing followed, appeared to depend on the population attained (which, in turn, depended on the size of 
TABLE II

Effect of homologous soluble-specific substance on the pneumococcidal action of immune serum and sulfapyridine in defibrinated human blood

\begin{tabular}{|c|c|c|c|c|c|c|c|c|}
\hline \multicolumn{3}{|c|}{$\begin{array}{l}0.5 \text { cc. patient's blood } t \\
\text { +0.1 cc. broth } \\
\text { containing }\end{array}$} & \multicolumn{2}{|c|}{$\begin{array}{l}\text { Pneumococcidal } \\
\text { action at } 3 \text { hours }\end{array}$} & \multirow{2}{*}{\multicolumn{2}{|c|}{$\begin{array}{c}\begin{array}{c}\text { Growth } \\
\text { inhibition }\end{array} \\
\begin{array}{c}\text { Largest inoeu- } \\
\text { lum showing } \\
\text { no color } \\
\text { change after }\end{array}\end{array}$}} & \multicolumn{2}{|c|}{$\begin{array}{l}\text { Pneumococcidal } \\
\text { action at } 48 \text { hours }\end{array}$} \\
\hline \multirow{2}{*}{$\begin{array}{c}\text { Im- } \\
\text { mune } \\
\text { rab- } \\
\text { bit } \\
\text { se- } \\
\text { rum }\end{array}$} & \multirow{2}{*}{$\begin{array}{c}\text { Sulfa- } \\
\text { pyridine } \\
\text { to make } \\
\text { final } \\
\text { concen- } \\
\text { tration }\end{array}$} & \multirow{2}{*}{$\begin{array}{l}\text { Pneu- } \\
\text { mocoo } \\
\text { cus III } \\
\text { culture } \\
\text { filtrate } \\
\text { (SSS) }\end{array}$} & \multirow{2}{*}{$\begin{array}{l}\text { Inocu- } \\
\text { lum }\end{array}$} & \multirow{2}{*}{$\begin{array}{l}\text { Organisms } \\
\text { viable } \\
\text { after } 3 \\
\text { hours' in- } \\
\text { cubation }\end{array}$} & & & \multirow{2}{*}{$\begin{array}{l}\text { Inocu- } \\
\text { lum }\end{array}$} & \multirow{2}{*}{$\begin{array}{c}\text { Organisms } \\
\text { viable } \\
\text { after } 48 \\
\text { hours' in- } \\
\text { cubation }\end{array}$} \\
\hline & & & & & $\begin{array}{c}24 \\
\text { hours }\end{array}$ & $\begin{array}{c}48 \\
\text { hours }\end{array}$ & & \\
\hline units & $\underset{\text { per }}{\operatorname{mom} .} .00$ & $c c$. & & & & & & \\
\hline 0 & 0 & 0 & 71 & $1,500 \pm$ & 0 & 0 & 7 & $\infty$ \\
\hline 0 & 0 & 0.05 & 71 & $1,500 \pm$ & 0 & 0 & 7 & $\infty$ \\
\hline 0.1 & 0 & 0 & $\begin{array}{r}71 \\
71,000\end{array}$ & $\begin{array}{l}0 \\
4\end{array}$ & 71,000 & 71,000 & 71,000 & 0 \\
\hline 0.1 & 0 & 0.05 & 71 & $3,000 \pm$ & 0 & 0 & 7 & $\infty$ \\
\hline 0 & 7.5 & 0 & 71 & $1,200 \pm$ & 71,000 & 71,000 & $\begin{array}{r}7,100 \\
71,000\end{array}$ & $\begin{array}{r}0 \\
40\end{array}$ \\
\hline 0 & 7.5 & 0.05 & 71 & $2,000 \pm$ & 71,000 & 71,000 & $\begin{array}{r}710 \\
71,100 \\
71,000\end{array}$ & $\begin{array}{l}\mathbf{0} \\
\mathbf{3} \\
\mathbf{3}\end{array}$ \\
\hline
\end{tabular}

ATTER ADMINISTRATION OF 10 GRAMB BULFAPTRIDINE IN 44 HOURS

\begin{tabular}{l|l|l|r|r|r|r|r|r}
\hline 0 & $8.0^{*}$ & 0 & 51 & $2,000 \pm$ & 51,000 & 5,100 & 51 & 0 \\
510 & 10 \\
600 \\
0 & $8.0^{*}$ & 0.05 & 51 & $2,000 \pm$ & 51,000 & 5,100 & 51 & 5 \\
510 & 0 \\
& & & & & & 5,100 & 82 \\
0.1 & $8.0^{*}$ & 0 & 51 & 0 & 51,000 & 51,000 & 51,000 & 0 \\
& & & 51,000 & $200 \pm$ & & & & 5 \\
0.1 & $8.0^{*}$ & 0.05 & 51 & $1,200 \pm$ & 51,000 & 5,100 & 51 & 0 \\
& & & & & & & 510 & 4 \\
\end{tabular}

† The blood used in this experiment was from a patient with pneumoccus Type III pneumonia. First blood taken on the fifth day. Blood culture showed no growth.

* Concentration of free sulfapyridine in the blood (total $=9.9$ mgm. per $100 \mathrm{cc}$.).

the inoculum), the concentration of the drug, and the susceptibility of the strain. The rate of killing, when it occurred, also depended on the same factors. Temperatures higher than $37^{\circ} \mathrm{C}$. may also enhance the action of sulfapyridine after the stationary phase. In defibrinated blood, which originally lacked pneumococcidal action, the results were similar to those obtained with the artificial media used.

The principal feature exhibited in all the growth curves was that multiplication of the bacteria in the presence of sulfapyridine was essential before any bacteriostatic or bactericidal action of the drug became evident. Mere exposure to the drug, as indicated by the results obtained at $5^{\circ}$. C. (Figures 10 and 11) was not enough to bring about the sulfapyridine effect. The lag in the action of the drug was apparently the same with concentrations of 5 and $10 \mathrm{mgm}$. per $100 \mathrm{cc}$.

These facts are important in any study of sulfapyridine action. The use of large inocula (7) or the use of methods such as the slide-cell technique of Fleming (4) which permit colony formation during the early growth phase may result in misinterpretations concerning the degree of bacteriostasis or of bactericidal action attainable with the drug. Like Fleming, we have noted small colony formation with faint hemolysis in agar plates poured with blood containing pneumococci and sulfapyridine during the active growth phase. We have also noted such small colonies in the blood of patients with massive bacteremia taken within a short interval after the injection of sufficient sodium sulfapyridine to raise the blood level to $10 \mathrm{mgm}$. per cent. These colonies presumably represent multiplication during the early logarithmic phase of growth. The bactericidal effect of the sulfapyridine also is evident because we have not been able to recover viable organisms from such colonies on subcultures, whereas normal looking colonies from the same plates grew freely when transplanted to fresh media.

Attainment of full growth is probably not the limiting factor in the action of sulfapyridine. This is borne out by a comparison of the curves obtained with large inocula of the stock Type III strain (Figure 3 ) and those obtained with the "Taylor" strain (Figure 6). In the former the maximum populations reached were well below full growth and these were attained at 4 hours and the decline that followed occurred at about the same rate as in the curves without the drug (Figure 1). With the latter strain, the curves which indicated that maximum growth was attained with the drug, also showed more rapid declines in the population as compared with the controls growing without sulfapyridine.

Another interesting phenomenon which occurred with several of the strains is illustrated in Figures 6 and 8 . With certain of the inocula the pneumococci were completely killed at $48^{\circ} \mathrm{C}$. in some experiments, while at other times the population was greatly reduced during a period of 4 to 24 hours only to remain static again or 
even to increase during the succeeding 24 hours or more. Whether or not this phenomenon was related to the development of drug-fast variants (10) within the population was not determined.

The results of the pneumococcidal tests confirmed and extended the previous findings with respect to the effect of sulfanilamide on pneumococcus growth in human blood (1). This drug was shown to be bacteriostatic for the 3 types of pneumococci tested in concentrations up to 20 mgm. per cent, and only occasionally was true bactericidal action noted within 24 hours when the higher concentrations were used. With sulfapyridine, bacteriostasis is effected by much lower concentrations. Even with this drug, however, more than $5 \mathrm{mgm}$. per cent is necessary in order to insure the regular occurrence of bactericidal action even for small numbers of pneumococci.

Homologous immune serum was shown to induce pneumococcidal action in fresh human blood. When used in small amounts in combination with small concentrations of sulfapyridine, the action is greater than when either agent is used separately. The action of the immune serum in such instances occurs early, as seen from the results of the 3-hour pour plates. The effect of sulfapyridine does not become evident for several hours.

Killing of the homologous type of pneumococcus occurs in the presence of sulfapyridine even in the blood taken before treatment from patients with massive bacteremia. Since certain amounts of the homologous soluble-specific substance are circulating in the blood of such patients, it would appear that the sulfapyridine action is not influenced by the presence of this substance. Even addition of further amounts of culture filtrate containing this substance in amounts sufficient to inhibit the action of added immune serum did not influence the action of sulfapyridine. These findings serve to explain, in part, why sulfapyridine may be effective even late in the course of pneumococcic infection and even in the presence of massive bacterial invasion of the blood. Except for the influence of focal purulent complications and perhaps other factors influencing the general reactions of the body, sulfapyridine should exert its beneficial effects in every case infected with a susceptible strain, provided the patient lives for several hours during which an effective concentration of the drug is maintained. Rapid destruc- tion of circulating bacteria could be effected by the use of immune serum, but for this purpose complement and an adequate number of intact leukocytes are probably essential $(15,16)$.

\section{SUMMARY AND CONCLUSIONS}

Growth curves in a favorable artificial medium and tests with human blood originally lacking in pneumococcidal properties indicated that sulfapyridine has considerable bacteriostatic and bactericidal action on pneumococci. The degree of bacteriostasis or of bactericidal action depends on the concentration of the drug and the number of pneumococci inoculated. Under the conditions of these experiments, growth invariably occurred before the sulfapyridine exhibited its effect.

Type-specific immune serum confers marked pneumococcidal properties on fresh human blood originally lacking in such properties. Both the sulfapyridine and the immune serum are effective in normal human blood and in the blood of patients with pneumococcic pneumonia. The combination of small amounts of serum and sulfapyridine is more effective than either agent used separately in the same amounts. The destruction of pneumococci in the presence of immune serum is rapid whereas the action of sulfapyridine is considerably delayed.

The immunological studies were carried out with the technical assistance of Mildred W. Barnes and Claire Wilcox. The chemical determinations were made by Margaret A. Adams and Nancy E. Marean.

\section{BIBLIOGRAPHY}

1. Finland, M., and Brown, J. W., Immunological studies in patients with pneumococcus Type III pneumonia treated with sulfanilamide and serum. J. Clin. Invest., 1939, 18, 307.

2. Finland, M., Spring, W. C., Jr., and Lowell, F. C., Immunological studies on patients with pneumococcic pneumonia treated with sulfapyridine. J. Clin. Invest., 1940, 19, 179.

3. McIntosh, J., and Whitby, L. E. H., The mode of action of drugs of the sulphonamide group. Lancet, 1939, 1, 431.

4. Fleming, A., The antibacterial action in vitro of 2(p-aminobenzene-sulphonamide) pyridine on pneumococci and streptococci. Lancet, 1939, 2, 74.

5. Long, P. H., Bliss, E. A., and Feinstone, W. H., The effects of sulfapyridine, sulfanilamide, and related compounds in bacterial infections. Pennsylvania M. J., 1939, 42, 483.

6. Reid, R. D., Observations on the mode of action of 
sulfapyridine on pneumococcus. Proc. Soc. Exper. Biol. and Med., 1939, 41, 437.

7. Hoyt, R. E., and Levine, M., In vitro studies on the action of sulfapyridine. Ibid., 1939, 40, 465.

8. Whitby, L. E. H., Chemotherapy of bacterial infections. Lancet, 1938, 2, 1095.

9. MacLean, I. H., Rogers, K. B., and Fleming, A., M. \& B. 693 and pneumococci. Lancet, 1939, 1, 562.

10. MacLeod, C. M., and Doddi, G., A "sulfapyridinefast" strain of pneumococcus Type I. Proc. Soc. Exper. Biol. and Med., 1939, 41, 69.

11. Marshall, E. K., Jr., and Litchfield, J. T., Jr., Determination of sulfanilamide. Science, 1938, 88, 85.

12. Enders, J. F., and Shaffer, M. F., Studies on natural immunity to pneumococcus Type III. I. The capacity of strains of pneumococcus Type III to grow at $41^{\circ} \mathrm{C}$. and their virulence for rabbits. J. Exper. Med., 1936, 64, 7.
13. Ward, H. K., Observations on the phagocytosis of the pneumococcus by human whole blood. I. The normal phagocytic titre and the anti-phagocytic effect of the specific soluble substance. J. Exper. Med., 1930, 51, 675.

14. Ward, H. K., Observations on the phagocytosis of the pneumococcus by human whole blood. II. The neutralization of the anti-phagocytic action of the specific soluble substance by antiserum. Ibid., 1930, 51, 685.

15. Robertson, O. H., Sia, R. H. P., and Cromwell, M. A., The activating effect of fresh normal serum on the pneumococcidal promoting action of antipneumococcus serum, Type I. J. Immunol., 1930, $19,429$.

16. Ward, H. K., and Enders, J. F., An analysis of the opsonic and tropic action of normal and immune sera based on experiments with the pneumococcus. J. Exper. Med., 1933, 57, 527. 